\title{
GAME EDUKASI FISIKA BERBASIS SMARTPHONE ANDROID SEBAGAI MEDIA PEMBELAJARAN FISIKA
}

\section{PHYSICAL EDUCATION GAME BASED ON ANDROID SMARTPHONE AS A PHYSICAL LEARNING MEDIA}

\author{
Widya Wati ${ }^{1}$, Heti Istiqomah ${ }^{2}$ \\ ${ }^{1}$ Prodi Pendidikan Fisika Fakultas Tarbiyah dan Keguruan Universitas Islam Negeri Raden Intan Lampung \\ ${ }^{2}$ MI Al-Khairiyah Tanjung Aji Lampung Timur \\ E-mail: hetiistiqomah59@gmail.com
}

Diterima: 14 Juni 2019. Disetujui: 15 Mei 2019. Dipublikasikan: 31 Juli 2019

\begin{abstract}
The purpose of this research and development is to develop mobile game physics based on program construct 2 which is a game designed to stimulate thinking power including increasing concentration and solving problems. This research method is research and development $(R \& D)$ based on the ADDIE model which consists of analysis, design, development, implementation, and evaluation. The method of retrieving data in this study is through the results of validation and testing of respondents. The validation results obtained from 5 validators with several aspects of assessment obtained an average of 3.70 with the category "feasible", so that from the results of validations obtained from experts, the educational game developed has better quality so that it is feasible to be implemented. The results of product trials on 30 students at Bandar Lampung Middle School 24 showed an average of 3.89 with the criteria of "very interesting". From the results of the trials of respondents the physics education game is very interesting to use as an enrichment media on temperature material and its changes.
\end{abstract}

Keywords: physical education game, android, learning media

Abstrak: Tujuan penelitian dan pengembangan ini yaitu mengembangakan mobile game eduaksi fisika berbasis program construct 2 yang merupakan permainan yang dirancang untuk merangsang daya pikir termasuk meningkatkan konsentrasi dan memecahkan masalah. Metode penelitian ini adalah research and development (R\&D) berdasarkan model ADDIE yang terdiri dari analisis, design, development, implementation, and evaluation. Cara pengambilan data pada penelitian ini yaitu melalui hasil validasi dan uji coba responden. Hasil validasi yang didapat dari 5 validator dengan beberapa aspek penilaian didapatkan hasil rata-rata sebesar 3,70 dengan katagori "layak", sehingga dari hasil validasi yang diperoleh dari para ahli, game edukasi yang dikembangkan memiliki kualitas yang lebih baik sehingga layak untuk di implementasikan. Hasil uji coba produk pada 30 peserta didik di SMP 24 Bandar Lampung didapatkan hasil rata-rata sebesar 3,89 dengan kriteria "sangat menarik". Dari hasil uji coba responden game edukasi fisika ini sangat menarik digunakan sebagai media pengayaan pada materi suhu dan perubahannya.

(C) 2019 Unit Riset dan Publikasi Ilmiah FTK UIN Raden Intan Lampung

Kata Kunci: game edukasi fisika, android, media pembelajaran

\section{PENDAHULUAN}

Perkembangan teknologi informasi yang semakin pesat dalam dunia pendidikan tidak bisa dihindari lagi pengaruhnya terhadap dunia pendidikan. Globalisasi telah memicu kecendrungan pergeseran dalam dunia pendidikan dari pertemuan tatap muka yang konvensional ke arah pendidikan yang lebih terbuka
(Budiman, 2017). Sistem oprasi sekarang ini menjadi bagian dari kurikulum yang mengatas namakan teknologi informasi (Tri Listyorini, 2013). Rosenberg menyatakan bahwa setidaknya ada lima pergeseran dalam proses pembelajaran yaitu dari pelatihan ke penampilan, dari ruang kelas ke dimana dan kapan saja, dari kertas ke online atau saluran, dari 
fasilitas fisik ke fasilitas jaringan kerja, dan dari waktu siklus ke waktu nyata (Gunawan, 2004). Inovasi pemebalajaran dengan memenafaatkan teknologi akan memeberikan suasana bebeda terhadap apresiasi peserta didik terhadap pembelajaran(Sujoko, 2007). Interaksi yang terjadi dengan adanya bantuan teknologi menjadi semakin mudah dan beragam (Husain, 2014). Teknologi memberikan banyak kemudahan sebagai cara baru dalam melakukan aktivitas manusia (Ngafifi, 2014). Dari tahun ketahun konsep ponsel terus berkembang semakin cangggih (Rahma, 2015). Selain digunakan sebagai alat komunikasi smartphone dianggap sebagai hiburan karena smarthpone lengkap dengan fiturfitur yang mudah digunakan. Fitur yang paling digemari dikalangan pelajar atau peserta didik dikala mereka bosan dengan pelajaran disekolahnya yaitu permaian atau game karna game memiliki tantangan tersendiri bagi pemain (Prasetio, Ertikanto, Suyatna, \& Lampung, 2015). Namun dalam kenyataannya mereka bayak memainkan game-game yang tidak bermanfaat dan malah menjadikan pemaian ketagihan untuk terus bermain game, sehingga lupa untuk belajar (Baswedan, 2015). Citra game di masyarakat masih dipandang hanya sebatas penghibur saja(Pane, Najoan, \& Paturusi, 2017).

Saat ini sudah banyak game untuk mengasah daya pikir dan logika yang dapat memperkenalkan materi agar lebih menarik untuk diterima dan dipahami (Dian Wahyu Putra, 2016). Untuk daya tangkap pemebelajaran pada saat ini lebih ditekankan kepada pendidikan visual yang terlihat menarik (Adiwijaya, S, \& Christyono, 2015). Banyak program yang digunakan untuk media pemebalajaran seperti e-learning, e-education, e-library, e-labortory dan sebagainya menawarkan inovasi dan kemudahan untuk proses pembelajaran menjadi lebih menarik dan menyenangkan, salah satu media pembealajaran populer saat ini adalah melalui game (Oktavia, 2015). Metode ini mampu mengakomodasikan keterbatasan jarak, waktu dan tempat untuk belajar. Sebagai landasan epistemologi teknologi pendidikan itu sendiri bahwa belajar bisa dilakukan kapan saja dan dimana saja dan oleh siapa saja (Yuberti, 2015).

Dapat dilihat hasil penyebaran angket mengenai penggunaan jenis smartphone yang digunakan peserta didik di SMPN 24 Bandar Lampung adalah jenis android $70 \%$, blackberry $10 \%$, iphone $15 \%$ dan lainnya 5\% sehingga di ketahui rata-rata siswa paling banyak menggunakan jenis smartphone yaitu sistem operasi android selanjutnya pada penggunaan smartphone di SMP Negeri 24 Bandar Lampung adalah untuk bermain game $40 \%$, chatting $35 \%$, youtube/video $20 \%$ dan lainnya $5 \%$ Sehingga di ketahui rata-rata siswa paling banyak menggunakan smartphone untuk bermain game.

Game yang memiliki konten pendidikan lebih di kenal dengan istilah game edukasi(Sumadi, Mulyani, \& Es, 2015). Game edukasi adalah salah satu jenis game yang digunakan untuk memberikan pembelajaran kepada penggunanya melalui media permainan yang mudah di pahami. Game edukasi memberikan kesempatan yang baik untuk merangsang pemikiran anak-anak (W.-M. Lee, 2011). Dengan bermain permainan pembelajaran, maka waktu yang digunakan untuk memainkan permainan tidak akan terbuang sia-sia (Sumadi et al., 2015). Untuk itu dikembangkan media belajar mobile game edukasi fisika sebagai pengayaan materi suhu dan perubahnnya.

\section{METODE PENELITIAN}

Metode penelitian ini adalah research and development (R\&D) dan menggunakan model ADDIE yang terdiri dari analysis, design, development, implementasi dan evaluasi. 
Dikembangkan oleh dick dan carry (muliyatiningsih,2012).

Pengembangan yang dilakukan pada tahap anlisis yaitu diantaranya dilakukan analisis kebutuhan penggunaan terhadap perangkat lunak yang akan dikembangkan, analisis spesifikasi produk yang cocok diterapakan, perangkat keras dan perangkat lunak yang dibutuhkan serta pengguna sistem. Tahap design dilakukan perancangan untuk menentukan genre atau jenis game, cara bermain, tingkat kesukaran dan level game. tahap development dilakukan validasi pada 5 ahli dengan aspek penilaian artistik dan estetika, kemudahan navigasi, penyajian game edukasi, kelayakan isi, kebahasaan, keefektifan pengguna, kejelasan dalam penggunaan, kemenarikan media dan keperaktisan tampilan media. Setelah divalidasi dan dinyatakan valid oleh para ahli selanjutnya dilakukan implementasi yaitu uji coba pada 30 peserta didk untuk mengetahui respon pengguna terhadap mobile game edukasi yang dikembangkan.

Validasi dan uji coba responden dilakukan penilaian angket berbentuk skala tingkat yaitu penilaian diberi simbol angka : sangat layak 4, layak 3, kurang layak 2 dan tidak layak 1. Data yang diperoleh dianalisis dengan rumus sebagai berikut:

Keterangan:

$$
x_{i}=\frac{\sum S}{S_{\max }} \times 4
$$

$\mathrm{S}_{\max }=$ Skor maksimal

$\sum \mathrm{S}=$ Jumlah skor

$\mathrm{X}_{\mathrm{i}}=$ Nilai kelayakan angket tiap aspek

Hasil validasi diinterpresentasikan seperti pada tabel 1 .

Tabel 1. Skala validasi media

\begin{tabular}{ccc}
\hline Rata-rata & $\begin{array}{c}\text { Kriteria } \\
\text { Kelayakan }\end{array}$ & Keterangan \\
\hline $3,25 \leq \mathrm{V} \leq 4,00$ & Valid & (Tidak revisi) \\
\hline
\end{tabular}

\begin{tabular}{|c|c|c|}
\hline $2,51 \leq \vee<3,25$ & $\begin{array}{l}\text { Cukup } \\
\text { Valid }\end{array}$ & $\begin{array}{c}\text { (Revisi } \\
\text { sebagian) }\end{array}$ \\
\hline $1,75 \leq \mathrm{V}<2,50$ & $\begin{array}{c}\text { Kurang } \\
\text { Valid }\end{array}$ & $\begin{array}{l}\text { (Revisi sebagian } \\
\text { dan pengujian } \\
\text { ulang materi) }\end{array}$ \\
\hline $1,00 \leq \mathrm{V}<1,75$ & \multicolumn{2}{|l|}{$\begin{array}{l}\text { Tidak } \\
\text { Valid }\end{array}$} \\
\hline $\begin{array}{l}\text { Hasil res } \\
\text { diinterpresents } \\
\text { Tabel } \\
\text { 2. Skala K } \\
\end{array}$ & \multicolumn{2}{|c|}{$\begin{array}{l}\text { respon peserta } \text { didik } \\
\text { entasikan seperti pada tabel } 2 . \\
\text { la Kemenarikan Media }\end{array}$} \\
\hline Rata-rata & \multicolumn{2}{|c|}{ Kriteria Kemenarikan } \\
\hline $3,25 \leq \mathrm{V} \leq 4,00$ & \multicolumn{2}{|c|}{ Sangat Menarik } \\
\hline $2,51 \leq \mathrm{V}<3,25$ & \multicolumn{2}{|c|}{ Menarik } \\
\hline $1,75 \leq \mathrm{V}<2,50$ & \multicolumn{2}{|c|}{ Kuang Menarik } \\
\hline $1,00 \leq \mathrm{V}<1,75$ & \multicolumn{2}{|c|}{ Tidak Menarik } \\
\hline
\end{tabular}

\section{HASIL DAN PEMBAHASAN}

Hasil analisis kebutuhan yaitu masih kurangnya penggunaan media elektronik yang menarik yang berfungsi sebagai pendamping belajar siswa yang dapat menunjang pemebalajaran dan adanya penyalahgunaan gadged dalam pembelajaran. Analisi spesifikasi media ini dibuat mengguakan perogram utama Construct 2 . Selain itu, pembuatan media ini juga menggunakan perogram pendukung yaitu Adobe Photoshop CS 6 . Media ini dijalankan menggunakan Smartphone android; Opration System Andoid minimum versi 4.0 (Jelly Bean); font $14 \mathrm{pt}$; jenis huruf pada materi Arial an Times New Roman. Anlisis peserta didik, karakteristik peserta didik yang perlu diperhatikan antara lain kemampuan akademik individu, fisik, motivasi belajar, latar belakang ekonomi dan sosial, pengalaman belajar sebelumnya, dsb

Hasil tahap perancangan yaitu tahapan media seperti beckground, karakter, tombol pada paint, pembuatan layout dan event sheet untuk menu, cara bermain, gerbang tiap game, ringkasan, quiz, perancangan penyajian materi. Berikut tampilan media dapat dilihat pada gambar 1: 


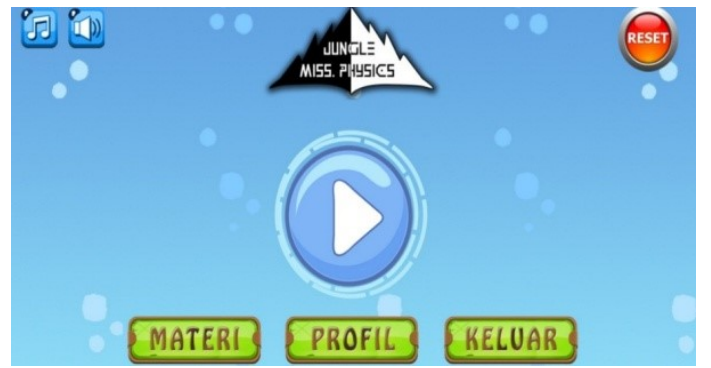

Gambar 1. Tampilan menu utama

Selanjutnya penyusunan instrumen penilaian kualitas produk yang telah dikembangkan berupa angket daftar isian.

Pada tahap pengambangan yaitu memvalidasikan game pada 5 ahli. Hasil penilaian pada setiap aspek oleh para ahli disajikan dalam bentuk grafik sebagai berikut:

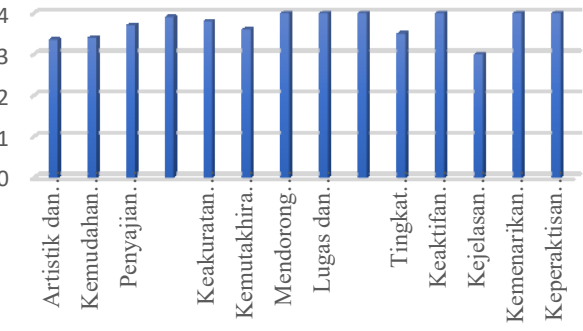

Gambar 2. Penilaian validasi

Hasil implementasi yaitu menguji cobakan media pada 30 peserta didik dapat dilihat pada tabel 3 .

Tabel 3. Uji Coba Kelompok Besar di SMPN 24 Bandar Lampung

\begin{tabular}{llllc}
\hline No & Aspek & Jumalah Skor & $\begin{array}{l}\text { Skor } \\
\text { Respon }\end{array}$ & Kriteria \\
\hline 1 & Kemenarikan & 340 & 29,18 & Sangat Menarik \\
2 & Kemudahan & 680 & 58,37 & \\
3 & Kemanfaatan & 340 & 29,18 & $\bar{x}=3,89$ \\
& Jumlah & 1,361 & 116,74 & \\
\hline
\end{tabular}

Pada tahap analisis dilakukan analisis kebutuhan dengan memberikan angket kepada peserta yaitu masih kurangnya penggunaan media elektronik yang menarik yang berfungsi sebagai pendamping belajar siswa yang dapat menunjang pemebalajaran dan adanya penyalahgunaan gadged dalam pembelajaran. Analisis spesifikasi produk media ini dibuat menggunakan program Construct 2 yaitu tool berbasis HTML untuk meciptakan sebuah permainan, tool construc 2 memungkinkan siapa aja membuat game tanpa harus memiliki pengalaman pemograman. Pembuatan media ini juga menggunakan program pendukung Adobe Photoshop Cs 6 untuk mendesain gambar dan kemenarikan warna. Media ini dijalankan pada smartphone android: opration system android minimum versi 4.0 (Jelly Bean); font $14 \mathrm{pt}$; jenis huruf yang digunakan pada materi suhu dan perubahannya adalah Times New Roman. Hasil analisis yang telah dilakukan digunakan untuk mengembangkan game edukasi fisika.

Pada tahap perancangan terdapat bagaian- bagian didalam game yaitu menu loading sebagai tampilan awal pembuka aplikasi. Tampilan menu utama yaitu terdapat tombol main, tombol materi, tombol profil dan tombol keluar. Menu level yang terdapat 10 level dalam permainan. Tampilan pop up petunjuk yang berisi petunjuk penggunaan game. Isi game yang didalam nya terdapat koin, kunci dan rintangan dan pada kunci terdapat soal yang harus dijawab untuk ke level selanjutnya. Pada pop up level complete merupakan jumlah koin yang didapat. Pop up game over akan muncul jika hati pemain tidak ada, masuk kejurang dan salah dalam menjawab pertanyaan. Pada isi soal mempunyai kesulitan disetiap tingkatan levelnya Dan tampilan menu materi yang menampilkan materi suhu dan perubahannya.

Pada tahap pengembangan dilakukan validasi kepada 5 ahli dengan aspek penilaian berikut: pada aspek artistik dan estetika diperoleh hasil rata-rata 3,35 dengan kriteria layak, aspek kemudahan navigasi diperoleh hasil rata-rata 3,4 dengan kriteria layak, aspek penyajian game memperoleh hasil rata-rata 3,7 dengan kriteria layak, aspek kesesuaian 
materi memperoleh hasil rata-rata 3,9 dengan kriteria layak, apek keakuratan materi memperoleh hasil rata-rata 3,8 dengan kriteria layak, aspek kemutakhiran materi memperoleh hasil rata-rata 3,6 dengan kriteria layak, aspek mendorong keingintahuan memperoleh hasil rata-rata 4,0 dengan kriteria layak, aspek lugas dan komunikatif memperoleh hasil rata-rata 4,0 dengan kriteria layak, aspek kesesuaian bahasa dan kaidah EYD memperoleh hasil rata-rata 4,0 dengan kriteria layak, aspek tingkat kesukaran game meperoleh hasil rata-rata 4,0 dengan kriteria layak, aspek keaktifan pengguna memperoleh hasil rata-rata 4,0 dengan kriteria layak, aspek kejelasan dalam penggunaan memeproleh hasil rata-rata 3,0 dengan kriteria cukup layak, aspek kemenarikan media memeproleh hasil rata-rata 4,0 dengan kriteria layak, dan aspek keperaktisan tampilan media memeproleh hasil rata-rata 4,0 dengan kriteria layak. Adapun kritik dan saran yang diberikan oleh para ahli pada saat melakukan validasi yaitu materi dan yang disajikan disesuaikan dengan $\mathrm{KI}, \mathrm{KD}$ dan Indikator, perbanyak gambar dan ilustrasi, pembuatan soal menggunakan kata kerja oprasional, tingkat kesulitan berdasarkan tingkat ranah kognitif, keserasian warna ditingkatkan agar lebih menarik, ditambahkan nuansa agama dalam game. Keritik dan seran yang didapat dari para ahli kemudian dijadikan sebagai acuan perbaikan sehingga mendapatkan kualitas game yang baik.

Hasil uji coba reponden dilakukan pada 30 peserta didik di SMPN 24 Bandar Lampung dengan beberapa aspek penilaian memperoleh hasil rata-rata sebesar 3,89 dengan kriteria sangat menarik. Pemilihan software Construct 2 merupakan perogram yang cocok untuk pembuatan game edukasi dikarenakan perkembangan teknologi, sehingga menyebabkan pengguna tertarik dalam memainkan game edukasi fisika. Game edukasi dapat digunakan sebagai pengayaan materi suhu dan perubahannya dan sebagai pendamping belajar siswa untuk menunjang pembelajaran. Sehingga dapat disimpulkan bahwa hasil akhir pengembangan mobile game edukasi fisika ini layak digunakan sebagai media pengayaan fisika pada materi suhu dan perubahnnya.

\section{KESIMPULAN}

Kesimpulan yang diperoleh dari penelitian dan pengembangan yaitu pada pengembangan Mobile game edukasi fisika ini,

1. Pembuatan media pembelajaran ini di awali dengan proses persiapan yaitu pembuatan background, karkter dan tombol pada paint dan adobe photoshop CS6, penyusunan materi menggunakan microsoft word 2016. Setelah proses persiapan selesai dilanjutkan dengan pembuatan game edukasi petualangan dengan program construct 2.

2. Penilaian yang didapat dari 5 ahli dengan beberapa aspek penilaian terhadap game edukasi ini termasuk dalam katagori sangat layak dengan nilai rata-rata 3,70 dari skor maksimum 4,00 dan skor minimum 1,00. Dari hasil validasi yang diperoleh dari para ahli, game edukasi yang dikembangkan memiliki kualitas yang lebih baik sehingga layak untuk di implementasikan

3. Respon peserta didik terhadap mobile game perhitungan skor rata-rata pada uji coba pada 30 peserta didik di SMP Negeri 24 Bandar Lampung diperoleh hasil rata-rata 3,89 dengan katagori sanagat menarik. Hal ini menunjukan bahwa game edukasi fisika yang telah dikembangkan sangat menarik bagi peserta didik dan dapat digunakan sebagai media pengayaan pada materi suhu dan perubahannya 
DAFTAR PUSTAKA

Adiwijaya, M., S, K. I., \& Christyono, Y. (2015). Perancangan Game Edukasi Platform Belajar Matematika Berbasis Android Menggunakan Construct2. Transient, 4(1), 129.

Budiman, H. (2017). Peran Teknologi Informasi dan Komunikasi dalam pendidikan. Al-Tadzkiyyah Jurnal Pendidikan Islam, 8, 76.

Dian Wahyu Putra. (2016). Game Android Berbasis Android Sebagai Media Pembekajaran Untuk Usia Dini, 1(1), 46-58.

Gunawan, Z. (2004). Pemanfaatan Teknologi Informasi dan Komunikasi (TIK) dalam Pembelajaran. Jurnal Ilmiah Pendidikan Fisika Al-Biruni, 3(1), 1.

Husain, C. (2014). Pemanfaatan Teknologi Informasi dan Komunikasi dalam Pembelajaran di SMA Muhammadiyah Tarakan, 2(2004), 184-192.

Ngafifi, M. (2014). Kemajuan Teknologi dan Pola Hidup Manusia dalam Perspektif Sosial Budaya. Jurnal Pembangunan Pendidikan; Fondasi Dan Aplikasi, 2(3), 33-47.

Oktavia, N. (2015). Pembuatan Game Edukasi Berbasis Construc 2 Sebagai Media Pembelajaran Fisika Untuk Siswa Sekolah Menengah Pertama. Prodi Pendidikan Fisika, (November), 56-67.

Pane, B., Najoan, X., \& Paturusi, S. (2017). Rancang Bangun Aplikasi Game Edukasi Ragam Budaya Indonesia. E-Journal, 12(1).

Prasetio, H., Ertikanto, C., Suyatna, A., \& Lampung, B. (2015). Pengembangan Game Edukasi Menggunakan Software RPG MAKER VX ACE pada Materi Hukum Archimedes, (1), 57-68.

Rahma, A. (2015). Pengaruh Penggunaan Smartphone Terhadap Aktifitas Kehidupan Siswa. Jurnal Fisip, 2(2), 7.
Sujoko. (2007). Pemanfaatan Teknologi Informasi dan Komunikasi sebagai Media Pembelajaran di SMP Negri 1 Geger Madium. Journal of Applied Physiology, 102(4), 1729-1731. https://doi.org/10.1152/japplphysiol. zdg-7173.corr.2007

Sumadi, C. D., Mulyani, S., \& Es, W. A. (2015). Pengembangan Media Game Senyawa Hidrokarbon Pada Pembelajaran Kimia si SMA Batik 1 Surakarta dan SMA Batik 2 Surakarta, 4(2), 82-88.

Tri Listyorini, A. widodo. (2013). Perancangan Mobile Learning Mata Kuliah Sistem Oprasi Berbasis Android. Jurnal SIMETRIS, 3(1), 25-30.

Yuberti. (2015). Online Group Discussion pada Mata Kuliah Teknologi Pembelajaran Fisika. Jurnal Ilmiah Pendidikan Fisika Al-Biruni, 4(2), 145-153. 